Page: 388-400 ISBN: 978-602-6 988-75-1

Web Jurnal Online: jurnal.unmuhjember.ac.id

By: Nita Ryan Purbosari

Reading Parks As A Waiting Room Services Center

In Pakusari Village Of Jember Regency

\title{
READING PARKS AS A WAITING ROOM SERVICES CENTER IN PAKUSARI VILLAGE OF JEMBER REGENCY
}

\author{
Nita Ryan Purbosari \\ (ryannita@ecampus.ut.ac.id) \\ Universitas Terbuka Jember
}

\begin{abstract}
Improving the quality of human resources rural communities is an important aspect of development that should be given serious attention. Innovation in public services the village is directed to provide added value to the quality of services while improve quality of human resources to achieve development goals. One such effort is the existence of the reading park as a waiting room at the Pakusari village office. This research aims to know more clearly how to use the park as a waiting room read villages and any service enabling and inhibiting factors such utilization. The research carried out by the primary data sources derived from direct observation and interviews and secondary data sources derived from the documents that support. As the reception area for the public service, there are five categories of responses and attitudes that indicate the level of indulgence or interest to read it, ranging from users who have an interest to read very well until the very lack of interest in reading. The results also showed 3 supporting factors and inhibiting factors in an effort to use the reading park as a waiting room Pakusari village office services. Besides to provide added value to the quality of service, as the waiting room reading park service is also expected to develop and increase reading interest as an important asset in the process of rural development.
\end{abstract}

Keywords: village development, village service, reading park. 


\section{INTRODUCTIONS}

The main purpose of national development is essentially to improve people's lives. This includes development in all fields and various aspects of people's lives, as well as the national development goals contained in the Preamble of the 1945 Constitution. The efforts to achieve national development goals also involve all levels of government, both central, provincial, district, sub-district and village. The villages are an important base in state life that has social, economic, political and social capital that must get the full attention of the government. So that in truth, the village development is an integral part of national development.

Since the enactment of Law Number 6 of 2014 concerning Villages, the position of the village has been transformed in 2 important aspects, namely the independent and the village as the center of development. The villages in an independent context lead to village authority to develop their potential in improving community welfare. This has received serious attention from the government with the allocation of village funds which are expected to spur the village development process. The village as a center of development is in line with the paradigm of village development which places society not as an object of development, but as the subject of development. Through this paradigm, village planning is more of a "buttom up" model with a participatory development model. The transformation of the village becomes more independent and as a center of development places the village as an important level in producing positive changes and progress for the village through efforts made consciously and programmed and involving synergies between citizens or institutions.

Looking further at village development, there are 2 main aspects, namely development in physical aspects and development in the human aspect or more commonly known as community empowerment. The development in physical aspects will be more related to physical infrastructure, while development in the human aspect is aimed at efforts to develop and enhance the potential of the community, thereby increasing the strength and independence of the economy, social and political. The term community empowerment is actually not a new thing in the construction context. However, until now the concept has become an important study both in theory and practice. This shows an awareness that humans are an important factor in development. Subeja and Narimo (in Mardikanto and Soebianto, 2012: 31) state that the process of community empowerment is a deliberate effort to facilitate local communities in planning, deciding and managing their own local resources aimed at achieving economic, ecological and social capability and independence. In language, empowerment comes from the word power which means strength, which get the prefix so that it means to have strength. The strength in question is strength in all aspects of life, so that efforts to build strength must also cover all aspects of people's lives.

The one important indicator that can be used in viewing village development is public services in the village. Based on Law Number 25 of 2009 concerning Public Services, it is stated that public policy is an activity or series of activities in order to fulfill service needs in accordance with the laws and regulations for every citizen and resident 
for administrative goods, services and / or services provided by public service providers. The organizer of public services in the village is the village government which includes the village head or what is called by another name assisted by village officials. To ensure that public services are carried out properly by supervisors, there are service standards that are used as benchmarks for service quality.

In facing global dynamics and the increasingly massive development of information technology, innovation in public services has become a potential breakthrough to improve quality and provide added value in services. The concept of innovation is often heard in the private sector as an effort to maintain products and the existence of companies in business competition. Innovation is a process that includes the appearence news idea, objects and applications are deliberately created, develop or new rediscovered (Wahyudi, 2016:53-54). Meanwhile in the public sector, innovation is carried out in the public domain as a whole. One of them is innovation in the implementation of public services. Furthermore, Dwiyanto (in Wahyudi, 2016:54) means that innovation is in the context public services as a application new idea in one or various aspects in public services that can provide added value. It means that a better change or increase the condition before innovation with condition after innovation.

The innovation in the implementation of public services carried out in Pakusari Village, Jember Regency is the existence of a reading park as a service waiting room. This reading park is intended as an effort by the village government so that service users or the community can get added value in services. In addition to getting the administrative services needed, the public can gain knowledge from reading materials available in the reading garden. This is also an effort that is simultaneously carried out by the village government to increase community power or the level of community empowerment as an important aspect of village development.

The existence of a reading park as a village service waiting room in Pakusari Village is something that is quite interesting, because it integrates 2 important concepts namely public service and community empowerment. Public services will have added value in efforts to empower the community and the community will also have new or increasing knowledge. Based on this explanation, the question arises about how the reading park is used as a village service waiting room. So, the purpose of this study is to find out more clearly how to use the reading park as a village service waiting room and what are the supporting and inhibiting factors of the utilization.

\section{RESEARCH METHODS}

This research uses a qualitative approach with descriptive types. The location of the research was in the Pakusari Village Reading Park, Jember Regency. The focus of this research is the use of reading parks by the community as a village service waiting room. This is seen from what activities are carried out by the community in the reading park. In addition, it also identifies what are the supporting and inhibiting factors of the utilization, both from the side of the village government, read the park manager and from the community side. 
The source of data in this research consisted of primary data obtained from interviews with village heads, managers of reading parks and residents of reading park visitors. The visitors to the reading park referred to in this study were community members who were waiting for village administration services in the reading room. Meanwhile, visitors who did not wait for services and did deliberately come to the reading park were not categorized in the data sources in this study. This is because the focus of this research is the reading park that is used as a village service waiting room. Meanwhile, direct observation of reading park activities was also carried out by researchers to obtain primary data sources. Secondary data sources are related to village and reading park documents that are relevant to the focus of research.

Checking the validity of the data is done by using the source triangulation technique, which compares and checks the degree of trust in information obtained through different times and tools. This is done by comparing observational data with interview data. Meanwhile, data analysis was carried out by analyzing the interaction models of Miles and Huberman which included data collection, data reduction, data presentation and data verification.

\section{RESULTS AND DISCUSSION}

a. Reading Park As a Village Service Waiting Rooms

The increasingly global dynamics of life and increasingly rapid development of science and technology, have consequences for changes in aspects of life. In facing this, surely every human being will carry out the learning process as a need to maintain and develop themselves to adjust to the environment and the demands of life. In a broader context, learning is needed by every citizen to be able to develop themselves and be able to contribute to the development process. With this learning, a person will gain knowledge that can improve the quality of a nation's human resources. As is known, Indonesia is a large nation that has abundant human resources and natural resources. This condition provides opportunities and potential for our nation to become a developed nation. However, until now Indonesia is still included in the category of developing countries which are still striving to solve various fundamental problems, including improving the quality of human resources. Based on that problem, learning becomes something that must be encouraged in people's lives.

During this time, learning is only required to be done by students or students or intellectuals only. In fact, learning must be done by all human beings and in the entire life process, better known as lifelong learning. Learning is very closely related to reading interest. Based on a book published by the Ministry of Education and Culture (2017: iii), data released by the 2015 Program of International Student Assessment (PISA) shows that the reading rate of Indonesian students is 64th in 67 countries. In addition, the 2012 UNESCO data also showed that reading interest in Indonesian society was 0.001 . That is, from 1,000 residents only 1 person has an interest in reading. This condition provides an awareness and reinforcement to us that people's reading interest needs to get attention from all elements of the nation. 
One of the efforts to develop and improve the reading interest of the people in Pakusari Village is the existence of a reading park. This reading park is also integrated as a village service waiting room. In a book published by the 2013 Directorate of Community Education Development, it was stated that the reading park is a facility or institution that aims to foster interest in reading to create a lifelong learning society. According to Hatimah (2013: 5.48), the benefits of the reading garden include:

a. Growing interest, love, and fondness to read

b. Enrich learning experiences and knowledge for the community

c. Growing independent learning activities

d. Helps develop reading skills

e. Add insight into the development of science and technology

f. Improve community empowerment

The Pakusari Village Reading Parks were established in 2017. The process of planning the development of the reading park was carried out through meetings involving village officials, hamlet heads, community leaders and youth organizations. Meetings are held to have the same perceptions and agreements about the existence and purpose of establishing this reading park. In this meeting were discussed and agreed upon several things such as the name of the reading park, the location of the reading park, the management of the reading park until what books should be provided in the reading park. The books that will be prepared come from the input of all meeting members representing each hamlet or group.

Based on the results of the meeting, it was agreed that the name of the reading park would be the Pakusari Village Reading Parks. This reading park is located in the Pakusari Village office, occupying 2 rooms in the Pakusari Village office with an area of $8 \times 4 \mathrm{~m}$. This reading park is made without reading tables and chairs, but is installed on a floor carpet as wide as the room. Reading books are placed on a shelf placed around the room. There are 7 reading racks with each measuring $2 \times 3 \mathrm{~m}$ and having 3 traps on each shelf. With the design of a room like this, in the middle of the room there is enough space to read. In addition, there is also a small / folding reading table in the reading park to support the learning process in the reading room.

The rapid development of information technology brings changes and progress in access to information. If in the past all information and knowledge was obtained through print sources, now online information sources are increasingly open with the existence of the internet. To accommodate these demands, then in the Pakusari reading park there is also a unit of computers connected to the internet network and equipped with a printer. This makes it easier for people to access various learning resources online. 
Page: 388-400 ISBN: 978-602-6 988-75-1

Web Jurnal Online: jurnal.unmuhjember.ac.id

By: Nita Ryan Purbosari

Reading Parks As A Waiting Room Services Center

In Pakusari Village Of Jember Regency

Reading books and supporting facilities available in the Pakusari Village reading park as in the table below:

Table 1. Reading Books and Supporting Facilities in Pakusari Village Reading Park

\begin{tabular}{lcl}
\hline Book Types and Supporting Facilities & Total & Unit \\
\hline Reading books for children & 77 & Copies \\
\hline Hobby books (cooking, household craft) & 54 & Copies \\
\hline Hobby Book (automotive, computer) & 26 & Copies \\
\hline Book of Religion Sciences & 24 & Copies \\
\hline General knowledge & 57 & Copies \\
\hline Books on agriculture, plantations, fisheries & 61 & Copies \\
\hline Healt book & 32 & Copies \\
\hline Child care & 9 & Copies \\
\hline Novel & 7 & Copies \\
\hline Educational Poster & 13 & Unit \\
\hline Small/folding reading table & 10 & Unit \\
\hline The Puzzle for children & 5 & Unit \\
\hline Crayon/Colour pencil & 5 & Pack \\
\hline Computer & 1 & Unit \\
\hline Printer & 1 & Unit \\
\hline Speaker & 1 & Unit \\
\hline Tradisional toys “congklak" & 5 & Unit \\
\hline
\end{tabular}

The table above shows that the books and learning support facilities found in the reading park of Pakusari Village are quite complete. This completeness is seen from the types of books available, ranging from books for children, hobby books to general knowledge books. In addition, the available books also cover the entire age of the community from children, adolescents/youth to households. This is so that the existence of this reading park can be utilized by all citizens. In addition, as a tool that is expected to be able to develop reading hobbies in the community, the reading park must also provide a comfortable and pleasant feeling for visitors. Therefore, this reading park also provides several learning resources for children's entertainment such as puzzles, colored pencils to traditional "congklak" toys. The existence of these supporting facilities is intended for children to make the reading garden a fun place to play, and slowly they will love the reading park. This love of the reading park can be a strong capital for children to love learning in the reading park.

In the carrying out its functions, the reading park in Pakusari Village has 3 administrators who are members of the Pakusari village youth club is called Karang Taruna. At the beginning of the establishment of the reading park until the end of 2018, it was this board that carried out all the park reading service activities. Initially this reading park has service hours every Monday to Thursday starting at 09:00 a.m until 12:00 p.m and 02:00 p.m until 03:00 p.m. While on Sundays, the reading park is only open if there are activities such as competitions. Although the socialization of the existence of the 
reading park has been carried out to the community, but based on the results of interviews with reading park administrators, the number of visitors to the reading park is still very low, around 10 to 15 visitors per week. If on certain days, the number of visitors is very large, it is usually dominated by high school students who are looking for information to do assignments. In addition, the reading park will be crowded with residents when there are important activities such as during the recruitment of prospective Civil Servants. Many residents come to find information on job vacancies for recruitment of Civil Servants and borrow their exam books.

In an effort to maximize the use of the reading park and develop community reading interest, starting in 2019 Pakusari Village Head made an innovation by making the park read as a waiting room for Pakusari village office services. The service is given to all citizens who need it or often referred to as public services. In Law Number 25 of 2009 concerning Public Services, it is stated that public services are activities in order to fulfill the service needs of every citizen provided by public service providers. Public service providers are every state-run institution, corporation, independent institutions formed by law for public service activities, and other legal entities formed solely for public service activities. In the village level, public service providers are village heads and village officials. Public services provided by the village include administrative and non-administrative services. In this study, services that are used as the focus of research are administrative services such as letter making services or information needed by the public.

There are various types of administrative services provided by the village apparatus for community members. In Pakusari Village, some of the services most often needed by residents include:
a. Services for making a National Identity Card (KTP)
b. Services for making domicile certificates
c. Family Card Making Service (KK)
d. Services for making Certificate of Not Married
e. Service for making marriage delivery letters
f. Service for making death certificates
g. Service for making certificate of heirs

However, there are still many other types of administrative services that are also the obligation of the village apparatus to provide services that are the rights of the community. If we study further, then the village office services are very broad and cover almost all administrative needs in the lives of every citizen.

In order to optimize the reading park as a service waiting room, at the beginning of 2019 the Village Head of Pakusari also appointed 2 village officials called the reading park companion. The companion will be on duty every day during working hours to provide services in the reading park, as well as one of them serving the community in administering administrative services. However, the implementation of the reading park escort assignments remained in coordination with the park management. With the presence of these two companions in the reading park management structure, it is 
expected that the residents who visit and utilize the reading park will be more improved and the reading park services will also be more optimal. Meanwhile, the management of the reading park from the Karang Taruna members will provide many services, especially outside of working days and hours.

In the reading park operation as a service waiting room, the service delivery phase is as follows:

a. Community service/applicants leaders meet with service personnel

b. The service clerk records service administration requirements and complete service requirements

c. The reading park companion directs applicants to wait in the reading garden

d. The companion invites service applicants to read reading books or guide/service service applicants who need information through the internet

e. The companion records applicants who borrow books

f. The service clerk provides the results of administrative services

In a research conducted from early January 2019 to the end of March 2019, there were 631 residents of the Pakusari Village who came to the village office to request administrative services. Thus, the average number of service applicants is approximately 200 applicants each month. Based on the number of 200 service applicants each month, the number of applicants per day is 10 . Providing services to 10 applicants every day is the same as the above stage, but not all community members / applicants provide the same response. Based on the results of interviews with reading park companion and direct observations, there are several types of community responses including:

a. $\quad$ Category 1 (Applicants enter the reading park, read and borrow books)

Applicants for services in this category can be considered as applicants who have a very good awareness and penchant for reading. While inside the reading park, these applicants will tour the existing bookshelves to see a collection of books. When the person in question has found an interesting book, it will immediately sit quietly and do reading activities. There are times when the applicant also goes directly to the desired shelf in accordance with the title on each shelf. Applicants in this category also do not hesitate to ask the park companion to read about the book they want to read. In conducting reading activities, the applicant is more calm and look focused. If the book that is read has not been completed, then the person concerned will borrow the book to take home. The number of applicants for services in this category 1 is $10 \%$ or 1 person out of 10 service applicants every day. Based on observations and interview with companions in reading park, the following are the characteristics of the category 1 service applicant activities while in the reading park to wait for services:

- First go around to the bookshelves, and sometimes go back to the previous bookshelf to pick up the book you want to read, or go to rack of books that you want based on the reading topic which write in rack

- Do not hesitate to ask the companion about the availability or existence of a book

- Do reading activities calmly and focus (usually it done while sitting)

Borrow books if you have not read them 
Some applicants, there are those who provide input to assistants for the type of procurement of the next book.

b. Category 2 (Applicants enter the park read and do reading activities)

The applicants for services in this category can be considered as those who already have a good awareness and penchant for reading. Applicants in this category will enter the reading garden and usually tour to see the collection of books on all the shelves. When finding a book that is considered interesting, it will be read at a glance while standing. Usually it only read in passing and not complete. That is how the applicant is waiting for the village administration services to complete. If administration services require a long waiting time, this applicant will usually sit while carrying a book. However, the person concerned is no longer focused and calm in carrying out reading activities. Usually it interspersed with other activities such as using cellphones. Applicants in this category seldom ask the companion about the availability of the desired reading book. The number of applicants for services in this category 2 is $40 \%$ or 4 people out of 10 service applicants every day. Based on observations and interviews with the reading park companion, the following are the characteristics of the category 2 service applicant's activities while in the reading park to wait for services :

- First go around to see the books on the shelf

- Read at a glance the books on the shelf (usually done while standing).

- If village administration services require a considerable amount of time, they will usually do reading activities while sitting, but there are other activities carried out such as using a mobile phone.

- Do not ask the companion about the availability or existence of a book

- Immediately put the books that are read if the required village administration services are completed

c. Category 3 (Applicants do not enter the reading park, but do reading activities)

The applicants for services in this category can be considered as those who have a good awareness and fondness for reading with special characteristics. When the village reading park companion invited to enter the reading park, the applicant for this service was not willing to enter. However, when the park companion reads several books that are considered attractive to service applicants, they read the book. This interesting book was chosen by the reading park companion based on several considerations, such as the profession and the fondness of the service applicant. For example, when the park companion reads to know or ask, it is known that the applicant for this service is a farmer, so the book prepared is agricultural books. Likewise, if the service applicant is a young man who likes to modify the motorbike, the books will be brought in related to his hobbies. They prefer to read outside the reading park, which is in the hall in the middle of the village office building, which has a large enough size, and without partition walls. They assume that the outdoor waiting room is more suitable and comfortable than in the room. The number of applicants for services in this category 3 is around $20 \%$ or 2 out of 10 people requesting services every day. Based on observations and interviews with the 
reading park companion, here are the characteristics of the category 3 service applicant activities:

- Read at a glance the books prepared by the reading park companion. However, there are times when they also read certain books until the awaited village administrative service is completed

- The waiting room for services is more comfortable in a hall / outdoor area that is open than being in a room.

d. Category 4 (Applicants enter the reading park but do not carry out reading activities)

The applicants for services in this category can be considered as those who lack awareness and interest in reading. The number of applicants for services in this category 4 is $10-15 \%$ or $1-2$ people out of 10 service applicants every day. When requesting administrative services in the village, the applicant is willing to enter and wait in the reading room, but does not carry out activities to read the reading books available in the safe reading. If you carry a cellphone, they usually use the cellphone. Based on the observations, the reading park companion has tried to invite them to read, but it still does not interest them. During the interview, the applicant said that it was not used to reading books and conveying that they would read later. In this category, the existence of books in reading parks and other supporting facilities that are quite complete cannot make applicants of this category interested in reading. This low reading interest is another thing that must pay attention to the management of the reading park to make a way that is more interesting for the community to read. They basically want to be in the reading park as a means of reading, only if there is something that is interesting for him to direct him to read. Based on observations and interviews with the reading park companion, the following are the characteristics of the category 4 service applicant activities while in the reading garden to wait for services:

- Enter the reading park, but don't read the books available

- The activity carried out is to keep silent or use a cellphone that is carried or talked with other service applicants who are waiting

- The greetings from reading garden companions cannot attract reading interest

- Completeness of reading park facilities cannot attract reading interest

e. Category 5 (Applicants do not want to enter the reading park and do not want to read)

The applicants for services in this category can be considered as applicants who have no interest in reading. The number of applicants for services in this category 5 is $10 \%$ or 1 person out of 10 service applicants every day. Although they have been welcomed to wait in the reading park, this applicant is not willing to enter the reading garden. In fact, when the village facilitator brought a number of books that were considered attractive to these applicants, the applicant still did not read them.

Supporting and Inhibiting Factors of Reading Parks as Village Service Waiting Rooms 
In an effort to use the reading park as a waiting room for Pakusari Village office services, there are several supporting factors and inhibiting factors. Supporting factors include the following:

\section{a. Available reading books variation}

The books available in the park read quite varied both in terms of the book title and the main segment of the users of the book. The main segments of the book available cover the entire age of the community, ranging from children to adults. Topics of books which are entertainment books, practical knowledge books, hobby books and others are also available in quite a number of titles.

\section{b. There are computer and internet facilities}

The rapid development of information brings changes in sources of information. If previously the community is accustomed to getting information through the source / print media, but now there has been a shift. Online information media that utilizes internet use is more often accessed by the public. This is because with the internet, we can get information anywhere, anytime and unlimited. This condition has also been addressed by the reading park in Pakusari Village by providing computers connected to the internet network. In fact, the printer has also been prepared if visitors want to bring home the results of the information obtained. Reading park visitors can take advantage of this facility free of charge. In fact, for visitors who are not yet skilled or unable to operate the internet, the reading park companion will guide or find the information needed.

\section{c. Special support facilities available for children}

In some cases, applicants for village administration services come to the reading garden together with their children. To facilitate this, there are also a number of supporting facilities for children such as crayons or color pens, puzzles, even traditional congklak toys, to facilitate this.

Meanwhile, some of the inhibiting factors for the use of reading parks as waiting rooms for Pakusari Village office services are as follows:

a. The reading park is in a room that is not adjacent to the village administration service room. The Pakusari Village Office has a "U" building facing east. In this building there are spaces that are used to support all activities in managing the village administration. In the center of this building, there is an open hall (without walls) that can be used for various purposes that can accommodate up to 100-150 people. At present, the reading garden occupies 2 rooms facing east, while the service room is on the other side facing north. The location of 2 spaces that are not adjacent or in the same direction, but which have an integrated function is still an obstacle for the service applicants and the reading park to guide the service applicants.

b. There is no flexible flow to integrate the reading park as a waiting room service. Integration of both of these services require a clear path so as to facilitate cooperation scheme for officials as well as the service requester. Flow describes in detail the stages of the administrative services of the village and the park service read. This groove at once leads to how the reading park has a strategic location with room service. Thus, the context of the workflow in that it has two meanings that describe the stages of service delivery 
and continuity between the administrative services and the service reading park. In the Pakusari village, two services are still not look aligned. When the applicant service comes, will be heading in the service space located on the south side. After that, they will go to the park reading on the west side. After the village administration services, the applicant will return to the room service. This condition is less strategic and efficient both for the applicant as well as service personnel services.

c. The reading park that just being in the room gives less flexibility for users to read. As the service user response in category 3, the applicant is not willing to read indoors reading garden, but prefer to read in the open hall. Reading in the room was considered too rigid and did not give freedom

\section{CONCLUSION}

Based on the discussion that has been described above, some of the conclusions in this research are as follows:

a. Reading parks is used as a waiting room at the Pakusari Village services is one of the innovations in the field of services that aim to provide added value to the quality of service and simultaneously develop and increase public interest as an important asset in the development process.

b. There are 5 categories of response and attitude on the existence of the park service users read as a waiting room. This category describes the activities of users of the service while in the reading park that indicates the level of indulgence or interest to read it, ranging from users who have an interest to read very good until have no interest in reading.

c. There are 3 supporting factors in the effort to use the reading park as a waiting room in Pakusari Village office services, namely variations in reading books, computer and internet facilities, and the existence of special support facilities for children.

d. There are 3 inhibiting factors in the effort to use the reading park as a waiting room for Pakusari Village office services, namely the reading park space which is not adjacent to the service room, there is no flexible flow to integrate administrative services with reading park services, and reading parks that are only provided the room does not provide flexibility in reading.

Based on these conclusions, there are several suggestions that can be used as considerations in an effort to improve the quality of the reading park as a waiting room for Pakusari Village office services, including:

a. Reading parks should provide a place to read which are outdoors. This is in order to provide flexibility for service users to choose according to their reading.

b. The location of the village administration services space and parks should read side by side for easy service requester and service personnel.

c. There is a clear flow of services that integrates stages of the administrative services of the village with reading park. This includes also serve applicants for services outside the room reading a book in the reading park. 
Page: 388-400 ISBN: 978-602-6 988-75-1

Web Jurnal Online: jurnal.unmuhjember.ac.id

By: Nita Ryan Purbosari

Reading Parks As A Waiting Room Services Center

In Pakusari Village Of Jember Regency

\section{REFERENCES}

Hatimah, Ihat dkk. 2013. Pembelajaran Berwawasan Kemasyarakatan. Tangerang Selatan : Universitas Terbuka.

Kementerian Pendidikan dan Kebudayaan Republik Indonesia. 2017. Panduan Penyelenggaraan Program Kampung Literasi. Jakarta : Direktorat Pembinaan Pendidikan Keaksaraan dan Kesetaraan.

Mardikato \& Soebianto. 2012. Pemberdayaan Masyarakat Dalam Perspektif Kebijakan Publik. Bandung : C.V. Alfabeta.

Moleong, L. 2001. Metodologi Penelitian Kualitatif. Bandung : Remaja Rosdakarya.

Wahyudi, Andi. 2016. Nilai Tambah Dalam Inovasi Pelayanan Publik : Praktik di Unit Pelayanan Terpadu di Kota Pontianak dan Kabupaten Tanah Bumbu. Jurnal Bina Praja. 8 (1) (2016). 